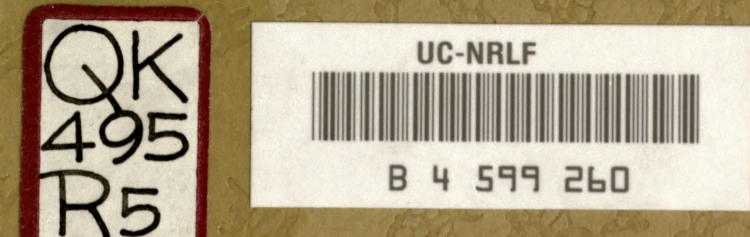




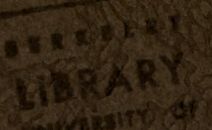

surionstx

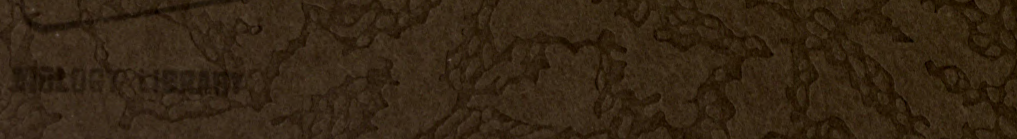

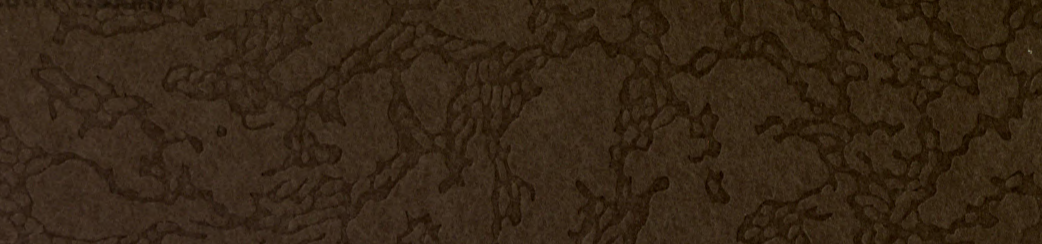

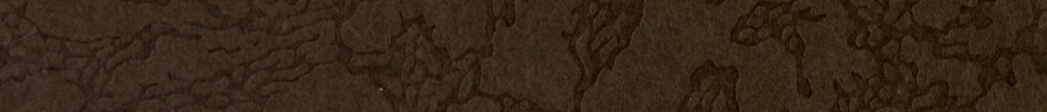

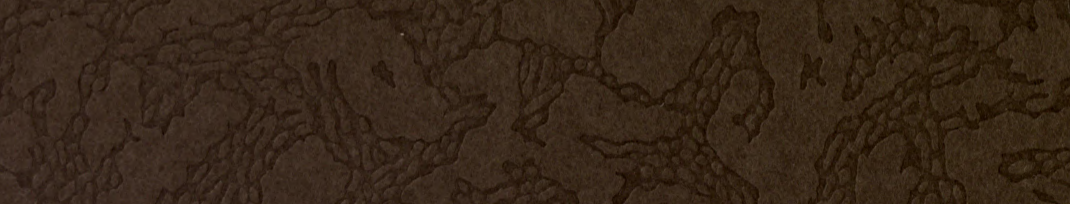

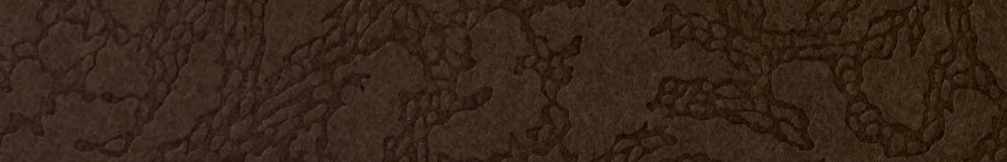

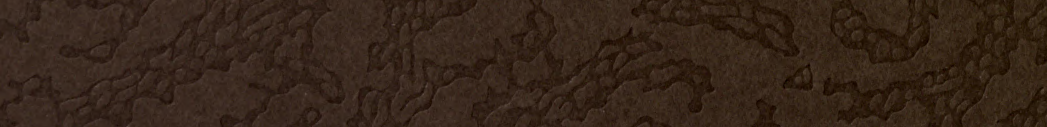

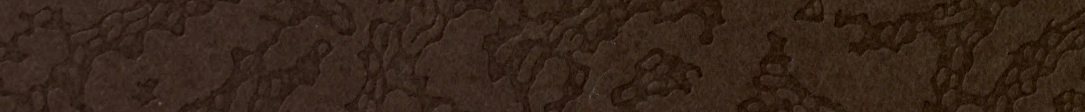

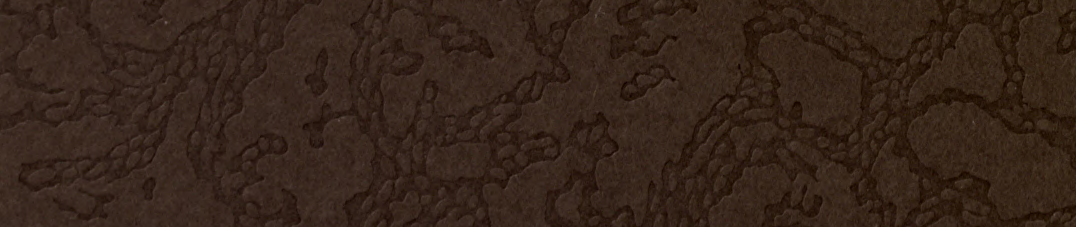

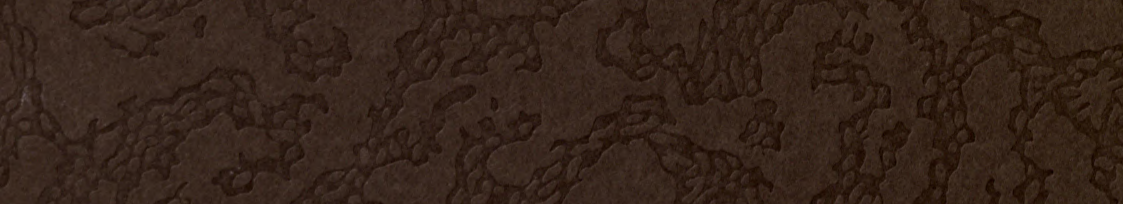

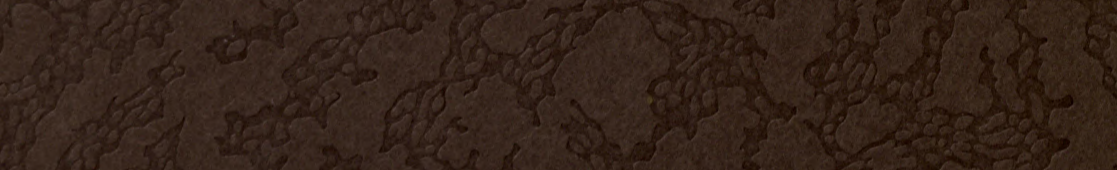

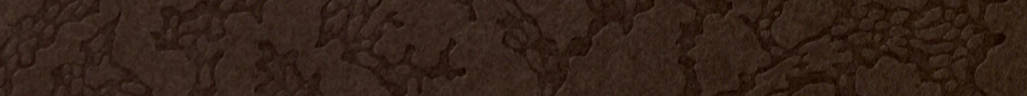

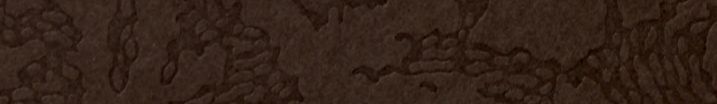

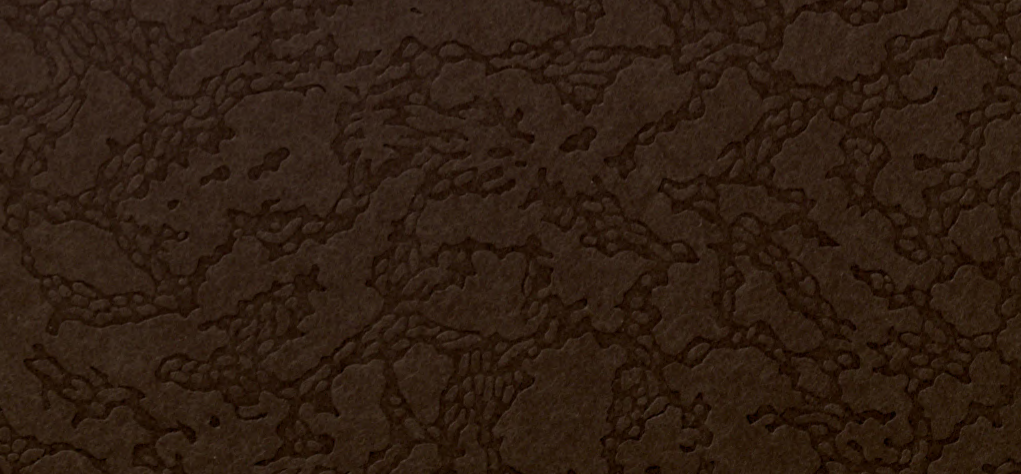




Qiin 10

$R 5 J_{3}$

BIOLOEY

LIBRARY

G

$$
\begin{aligned}
& \therefore \because \because \because \because \quad \therefore \quad \because \\
& \because \cdots \cdots, \because \because \because \because \cdots
\end{aligned}
$$

$6 a_{1}:$

4xy?

Main Lib.

Forcatry 


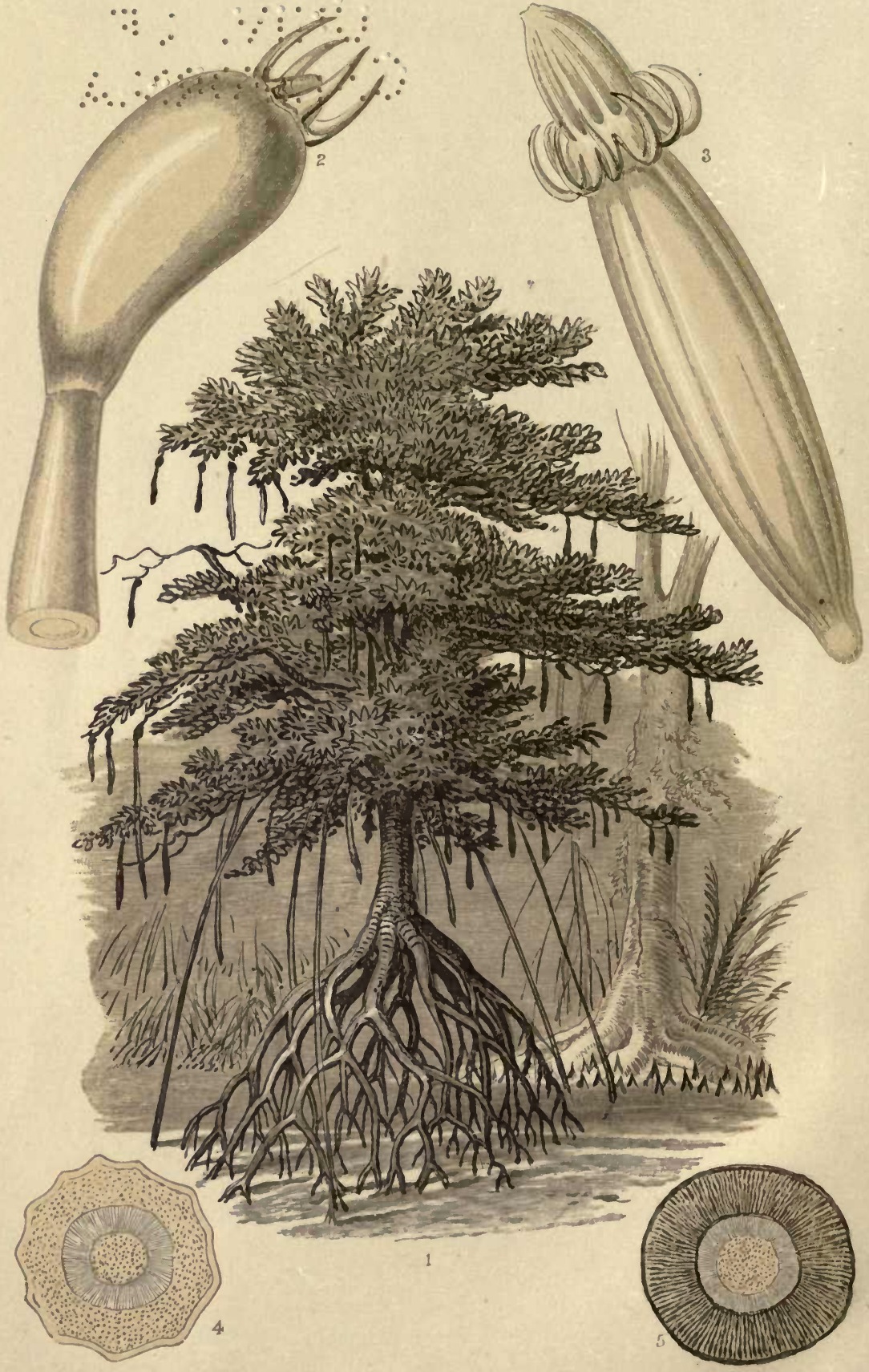




\title{
THE MANGROVE AND ITS ALLIES.
}

\author{
BY JOHN R. JACKSON, \\ Curator of the Museum, Royal Gardens, Kew.
}

(With a Tinted Plate.)

THE peculiar manner of growth of the Banyan, and other allied species of Ficus, we noticed in a recent number of the INTELLECTUAL Observer. In the Moraceee, it will be recollected that the habit of increasing the circumference of the plants, is by the downward growing branches, which strike root upon meeting the ground. In the Rhizophora, another singular, though very distinct mode of growth occurs, and of this the Mangrove is a well-known example. Most of our readers are aware of the existence of such a plant; but some of them may, perhaps, not be so intimately acquainted with it as to understand clearly its mode of germination ; nor are they, perhaps, aware that there is more than one species of Rhizophora, having the same peculiarity.

The name of Mangrove is associated in our minds with very unfavourable ideas of locality, we have read of Mangrove swamps, and we have notions of stagnant or muddy shores, fostering malaria or disease. We most of us know so much of its habitat; but we will endeavour to explain to our readers a little more about the Mangrove and its allies.

The genus Rhizophora, then, gives the title to a distinct natural order called Rhizophoracece, and placed according' to the latest authority, Hooker and Bentham's Genera Plantarum, between Haloragece and Combretaceo. The order is divided into three tribes: Rhizophoroe, Legnotidae, and Anisophylloe, numbering in all seventeen genera, and the four comprising the tribe Rhizophorce, have a similar habit of germinating their seeds before leaving the parent, these four genera are Rhizophora, Ceriops, Kandelia, and Brugueira.

The order is entirely a tropical one, and consists of trees or shrubs, mostly inhabiting the sea shore. The leaves are opposite, and the flowers usually axillary, the lobes of the calyx are valvate, not imbricate, the stamens arise from the same point as the petals, and are twice or three times their number, though in Kandelia they are indefinite. The ovary or fruit is sometimes superior, or seated above the calyx, as in Rhizophora, the calyx is persistent in several of the species.

The genus Rhizophora is distinguished from its allies, by the calyx being divided into four parts, the four petals sharply pointed, and the stamens which are from eight to twelve in number, having short filaments and anthers with littlo pits,

VOL. XI. - YYO. I. 
containing the pollen. The ovary is partially adherent, and contains two cavities in the part where it so adheres, each of these cavities bearing two ovules; the free part tapers towards the top into a single style.

The Mangrove, Rhizophora Mangle, I., is an evergreen tree, rising some forty or fifty feet high, and presenting a very singular appearance, both as regards the appendages of its branches, and its peculiar manner of rooting. The following description of the Mangrove, is from a paper, read before the Pharmaceutical Society, by Dr. Hamilton, in June, 1846.-"The Mangrove is a tree frequently of imposing stature, attaining an altitude of from thirty to fifty feet or more, and occupying marshy situations, in the vicinity of the sea, as at the bottom of English Harbour, Antigua, and near the mouth of the little river which empties itself into the harbour, at Cape Henri, Hayti. Its roots rise in the form of arches, above the muddy soil in which it grows, and affords attachment to myriads of small but delicious oysters, which are left bare during the efflux of the tide, giving rise to the popular fable of oysters growing on trees, which, with the exception of their not being fed by, but merely adhering to the tree, is literally true. These oysters make a most incomparable soup, of which I once partook at the house of an American merchant, at Cape Henri.

"The shade of these trees affords harbour during the day to innumerable swarms of mosquitoes, which nestle on the under surface of the leaves, and infest the houses of those who have the misfortune to live in the vicinity of a Mangrove swamp during the night.

"But in the economy of nature, the Mangrove performs a most important part, wresting annually fresh portions of the land from the dominion of the ocean, and adding them to the domain of man; this is effected in a two-fold manner, by the progressive advance of the roots, and by the aerial germination of the seeds, which do not quit their lofty cradle, till they have assumed the form of actual trees, and drop into the water with their roots ready prepared to take possession of the mud in advance of their parent stems, and repel to a further and perpetually increasing distance the invasion of the water. The progression by means of the roots is effected by fresh roots, which issue from the trunks, at some distance above the surface of the water, and arching downwards, penetrate the mud, establishing themselves as the pioneers of fresh invasions of the retiring element. In this manner the plants soon after their descent from their parent trees, continue, during their early years, to advance steadily forward till they have attained a height of about fifteen feet, and considerably in advance of 
their parent trunks. After this, fewer additions are made to the roots, but the head begins to expand in every direction, spreading its branches on all sides; these branches in their turn, send down long slender roots, like those of the Banyan fig tree (Ficus Indica), which, rapidly elongating, descend from all varieties of height, and reaching the water, penetrate the mud, becoming in time independent trees; thus a complicated labyrinth of vegetation is at length formed, serving to arrest the particles of soil washed down from the interior; theso, by their accumulations, raise the level of the ground, till at length what had been water, is converted into a salt marsh; and what had been a salt marsh, becomes progressively dry land, fit for the cultivation of man, and teeming with fertility from its copious intermixture with the exuviæ of marine animals and vegetables." The author of this description, compares the germination of the Mangrove to that of the Banyan, in "sending down long slender roots ;" but it must be borne in mind, that these roots in the Rhizophora, are not spongioles, borne at the ends of the branches, but are the true radicles, and the only difference to the general law of vegetable life, is that they germinate before leaving their parents, so that the long stick-like protuberance from the fruit, is the young root, which reaches downwards towards the ground as far as possible, and when no longer able to hold on to the parent, drops into the mud below, and then sends out its rootlets; the rudiments of which are clearly distinguishable on the surface of the radicles, as they hang from the trees.

Dampier, in his voyages, says: "The Red Mangrove groweth commonly by the sea-side, or by rivers and creeks. It always grows out of many roots about the bigness of a man's leg, some bigger, some less, which, at about six, eight, or ten feet above the ground, join into one trunk or body that seems to be supported by so many artificial stakes. Where this sort of tree grows it is impossible to march by reason of these stakes, which grow so mixed one among another that I have, when forced to go through them, gone half a mile and never set my foot on the ground, stepping from root to root. The timber is hard, and good for many uses; the inside of the bark is red, and it is used for tanning of leather very much all over the West Indies."

In places where Mangroves abound, the propagation is effected by the simple and natural process of the germinating seeds dropping into the mud and immediately throwing out their rootlets. The fruit, before germination takes place, is described as being edible and of a sweet flavour, the juice of which is fermented and made into a kind of wine. The economic uses of the Mangrove are very many. A kind of 
rough salt is extracted in Borneo from the aerial roots, and the wood is considered the best firewood of any produced in the island. The bark is well known as a tanning bark, for which purpose it is much valued; indeed, it has been said to equal, if not to excel, oak bark in the quantity of tannin which it contains. It is also used for dyeing, producing, in conjunction with mineral salts, olive, brown, and slate colours.

It is not the bark alone that contains tannin, but all parts of the plant. The leaves and roots of some of the species are used in the Mauritius and the West Indies for poultices; and in the last-named islands, as well as in the Phillipines, the bark is considered a good febrifuge. There are four or five species of Rhizphora known.

Ceriops stands next to Rhizophora in scientific classification. Two or three species are described, natives of Eastern Africa, Asia, Australia, and Polynesia. One of the distinctive characters of this genus is the five parted persistent calyx; the petals, also in fives, are pubescent or hairy at their points; and the ten stamens are seated two together in front of the petals. The bottom part of the ovary has three cells, each cell containing two ovules, the upper part of the ovary terminating in a long style, and the seed germinates before leaving the tree in a similar manner to that of Rhizophora.

Kandelia is a genus of which but one species is known, namely, Kandelia Rheedii, W. et A. It is a native of the East Indian Islands. The parts of the flowers of this, like the lastnamed genus, are in fives, but it is distinguished chiefly by the petals being divided and sub-divided into numerous fine divisions, and seated in a fleshy rim or disk, which lines the calyx tube. The stamens are indefinite, the filaments very fine, and the anthers small and oblong. The flowers are white and green; the fruit is ovoid, coriaceous, one-celled, and oneseeded, germinating on the trees as in Rhizophora. The bark of this tree, mixed with ginger or long pepper, and rosewater, is a reputed medicine among the native practitioners in India for the cure of diabetes.

Brugueira is a genus having six or eight species, natives of Eastern Africa, Australia, and the Polynesian Islands. They are trees frequenting the shores of rivers and muddy swamps, and are known from the preceding genera by the numerous lobes or limbs of the calyx, varying from eight to about fourteen, which adhere to the ovary below, thus making the calyx superior, or seated above the fruit, and standing up in a whorl round the radicle. From this arrangement of the sepals, the radicle might easily be mistaken for an elongated fruit. The petals agree in number with the sepals; they are coriaceous, and woolly at the edges, and cleft or divided in two parts. 
The number of stamens are from sixteen to twenty-eight, and are placed as in Kandelia, in pairs, opposite the petals, and each petal is folded so as to form a hiding-place for the filament. The ovary has from two to four cells, each cell containing two ovules. The fruit being inferior, and the calyx persistent, it remains at the apex of the fruit; and when germination takes place, it is simply pushed away from the centre to make room for the young radicle. In this genus the roots are thrown up from below all round the root, as shown in plate.

The internal structure of the main root of the mangrove (Rhizophora Mangle, L.), as shown in a cross section, differs from that of the radicle. A good idea of the former may be had from Fig. 4, the outer and the central parts of which are masses of reddish brown fibrous tissue, while the ring is a very white, hard, woody substance, with clear and distinct rays crossing it in a direct line. A section of the radicle shows in the centre a mass of loose fibre surrounded by woody tissue, made up of silky fibrous bundles, the whole of a similar colour to the true root. The outer covering is composed of fine bundles of close, hard, woody fibre, arranged more or less regularly parallel.

The root of Brugueira shows in a cross section (Fig. 5) a similar arrangement to that of Rhizophora, except that the portion between the outer epidermis, or cuticle, and the ring of wood, is composed of thin paper-like divisions, regularly arranged, instead of an indiscriminate mass of fibrous tissue. These divisions, as will be seen by the figure, are very evenly placed, radiating from the centre. The appearance of one of these papery walls under the microscope is very singular and beautiful, presenting a mass of fine, glittering, scale-like markings.

\section{DESCRIPTION OF THE PLATE.}

Fig. 1.-Mangrove tree, Rhizophora Mangle, L. To the right is seen a tree of Brugueira sp., showing its singular manner of throwing up its roots.

FIg. 2.-Germinating fruit and purtion of the radicle of Rhizophora Mangle, L., showing the inferior calyx.

FIG. 3.-Germinating fruit and radicle of Brugueira sp., showing the superior calyx. This is here represented as being reflexed, having been drawn from a dried specimen. It stands erect when fresh.

Fia. 4.-Cross section of root of mangrove, Rhizophora Mangle.

FIa. 5.-Cross section of root of Brugueira sp. 


\section{THE MAMMOTH AND ITS EPOCH.*}

Tue discovery of the bodies of enormous animals akin to the elephant in the frozen soil of Siberia has excited the astonishment of naturalists and of the vulgar. The primitive nomads regarded them as monstrous burrowing rats, whose life was extinguished as soon as they saw the light of day; and the Chinese supposed that their subterranean movements gave rise to earthquakes. It has been generally supposed that Siberia had, in the mammoth days, a mucl warmer climate; M. de Middendorff disputes the conclusion, and states that the wood found in N. Siberia, and supposed to have grown there, is in reality drift-wood. It is also remarked, that the hypothesis of former heat in the Siberian climate would not solve the enigma, as it would not explain the good preservation in which the bodies of the great animals has been kept, which would seem only possible in a frozen soil, and the climate could not have changed so suddenly as to leave no time for their decomposition. Besides, the mammoths were well fursished with hair, and were not intended, like the modern elephants, to inhabit hot countries. Fir needles have been found between the teeth of rhinoceri, buried by the side of the mammoth, indicating that the latter may have lived in forests of conifers; but what was its food in the steppes which are beyond the limits of arborescent vegetation? M. de Middendorff supports the opinion that the bodies of the mammoths were drifted from more southern regions; but if this were the case, how is it that their bodies came to be so perfectly preserved in ice, and how was the congelation effected? Is it possible, as Adams thinks, that they found their sepulture in the midst of pure compact ice, and have been preserved there for millions of years?

On the recommendation of M. de Middendorff, the St. Petersburg Academy offered rewards of 100 to 150 roubles for the discovery of a complete mammoth skeleton, and of 300 roubles for that of a body with the soft parts entire. At Christmas, 1865, M. K. C. Von Baer received from Barnaul : 2 notification that a Samoyede-Jurack had found an entire mammoth in 1864, with its skin, near the Bay of Tas, which opens into the Gulf of Obi.

This discovery, which was mentioned in former numbers of the Intellectual Observer, induced the Academy of St. Petersburg to send M. Frederic Schmiat to the spot. On the 24th March (last) he arrived at Yenissek, and from thence forwarded a piece of the mammoth's skin, which had been

* Abridged from an article in the Archives des Sciences, No. 108. 



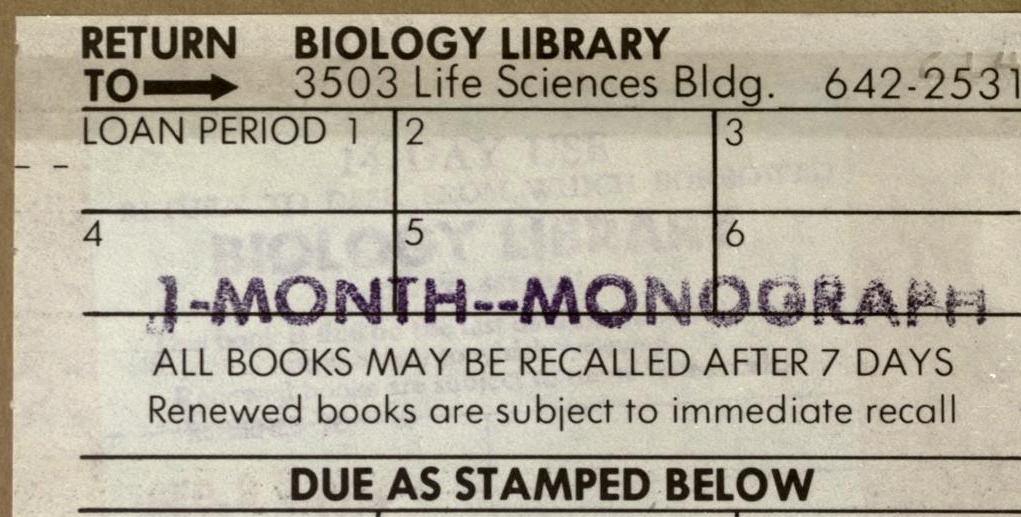

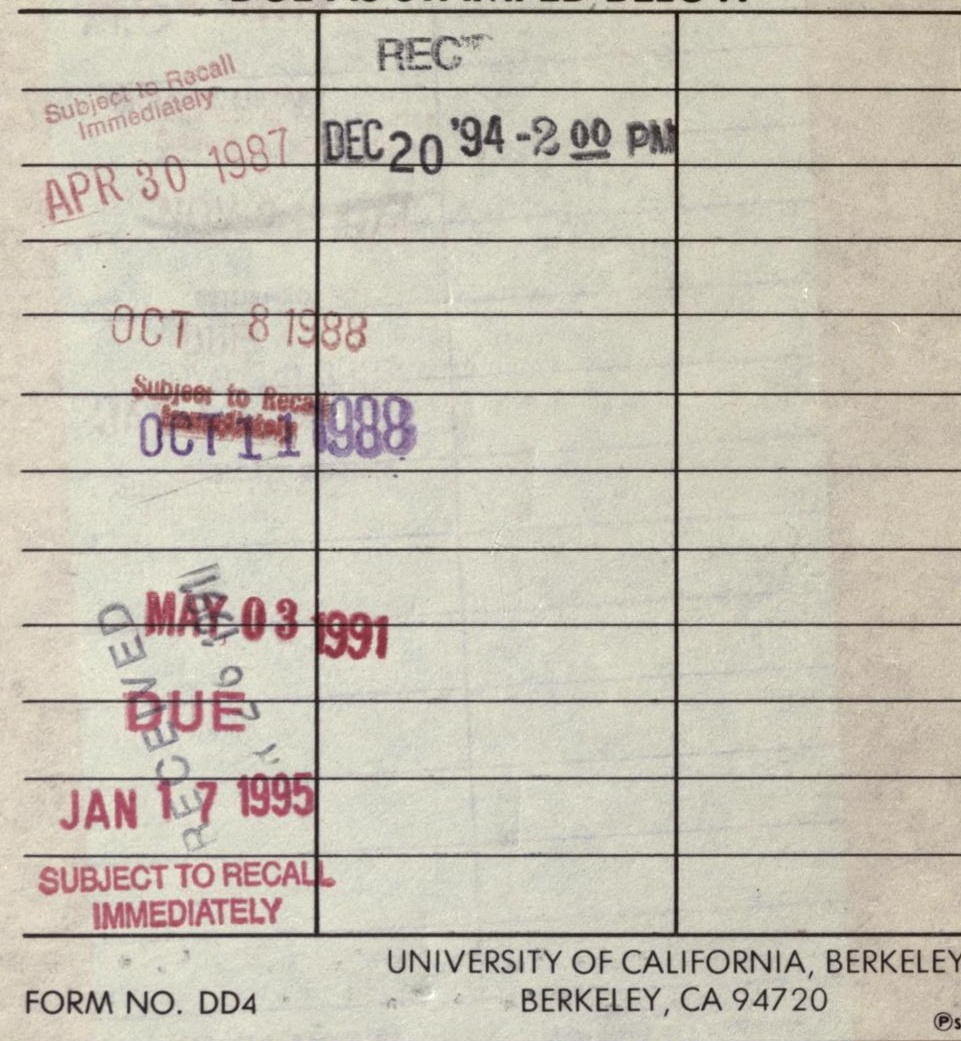




\section{U.C. BERKELEY LIBRARIES}




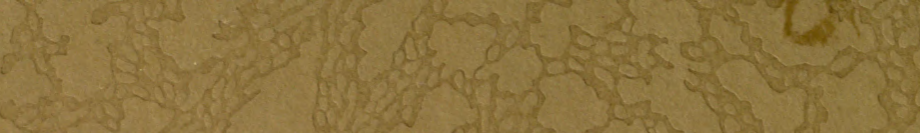

